\title{
Phylogenetic Relationships among Palearctic and Nearctic Whitefish (Coregonus sp.) Populations as Revealed by Mitochondrial DNA Variation
}

\author{
Louis Bernatchez ${ }^{1}$, and Julian J. Dodson \\ Département de biologie, Université Laval, Sainte-Foy, QC G1K 7P4, Canada
}

\begin{abstract}
Bernatchez, L., and J.J. Dodson. 1994. Phylogenetic relationships among Palearctic and Nearctic whitefish (Coregonus sp.) populations as revealed by mitochondrial DNA variation. Can J. Fish. Aquat. Sci. 51(Suppl. 1): 240-251.

We recently documented the existence of two highly distinct mitochondrial DNA (mtDNA) phylogenetic groups of Coregonus sp. in Beringia in the absence of geographic separation. To test whether this resulted from secondary intergradation of two groups that evolved in allopatry in Eurasia and Beringia, mtDNA restriction-fragment-length polymorphisms of 210 whitefish representing 22 populations from Europe and Siberia were compared with mtDNA variation observed among 581 fish from North America. Results confirmed that Beringia represents a zone of secondary contact among endemic whitefish and a group of Eurasian origin. All Beringian populations clustered much more closely to Eurasian populations than other North American ones. We also compared mtDNA variation among Palearctic populations with that observed in North America. European populations clustered into two major mtDNA groups that exhibited a strong geographic pattern of distribution, independent of the morphological variation observed among populations: one dominated all the more northern populations and extended to Alaska-Yukon; the second largely dominated samples from central alpine lakes, and was absent from Beringia. These results suggest that central alpine lakes and northern Europe were postglacially recolonized by two genetically distinct whitefish groups that most likely evolved in allopatry followed by limited intergradation.
\end{abstract}

Nous avons récemment identifié deux groupes phylogénétiques de corégones (Coregonus sp.) en Béringie. Afin de vérifier l'hypothès voulant que le chevauchement de ceux-ci résulte d'un contact secondaire entre groupes allopatriques ancestraux, nous avons comparé la variation de l'ADN mitochondrial au sein de 210 corégones représentant 22 populations d'Eurasie à celle observée en Amérique du Nord. Les résultats ont confirmé l'hypothèse voulant que la Béringie représente une zone de contact secondaire entre un groupe de corégone endémique et un autre d'origine eurasienne. Toutes les populations béringiennes étaient plus apparentées aux populations européennes qu'à celles peuplant le reste de l'Amérique de Nord. D'autre part, les populations eurasiennes se divisaient en deux groupes génétiques démontrant une répartition géographique distincte, indépendamment de la variation morphologique. Un groupe dominait toutes les populations nordiques et se retrouvait jusqu'en Alaska et au Yukon. Le deuxième groupe dominait largement les populations lacustres des Alpes. L'ensemble de ces résultats suggère donc que les lacs alpins et l'Europe du nord ont été colonisés par deux groupes de corégones phylogénétiquement distincts qui ont évolué en allopatrie et entre lesquels le flux génique est demeuré restreint suivant leur dispersion postglaciaire.

Received June 1, 1993

Accepted July 28, 1994

Reçu le $1^{\text {er }}$ juin 1993 (J12441)

Accepté le 28 juillet 1994

$\mathbf{P}$ leistocene glaciation events are assumed to have dramatically altered the genetic population structure of northern fauna and flora (Denton and Hughes 1981). Alternate phases of glacial advances and retreats may have been as important in promoting radiation of local populations as in favoring intermittent gene flow among them through their subsequent dispersal (Briggs 1986). Thus, during glacial advances, several races may have been created by temporal and geographical isolation in separate glacial refugia. Conversely, the opening of dispersal routes has provided opportunities for gene flow among newly emerging races.

Northern freshwater fish species remained geographically isolated in separate drainages during the maxima of Pleistocene glaciations. However, these geographically isolated

\footnotetext{
${ }^{1}$ Corresponding author.
}

populations were intermittently provided with opportunities for widespread dispersal. Thus, major continental dispersal routes became available during phases of deglaciation through the creation of large-scale hydrographic connections and development of proglacial lakes associated with glacier melting (Fulton and Andrews 1987). Opportunities for intercontinental dispersal of freshwater fishes were also created during phases of glacial advance by the episodic openings of the Bering land bridge, classically recognized as the major route for faunal exchange between Eurasia and North America (Kontrimavichus 1973; Lindsey and McPhail 1986).

The whitefishes are members of the family Salmonidae and have a continuous circumpolar distribution in the northern hemisphere. The Palearctic and Nearctic populations of whitefish have classically been divided into two major nomenclatural species complexes based on continental distribution; 
the European whitefish (Coregonus lavaretus) and the lake whitefish (Coregonus clupeaformis). The wealth of phenotypic variation observed in whitefish had led to various taxonomic interpretations of numerous geographical and ecological forms within each species complex (Berg 1948). This situation had led to a very confusing and inconsistent nomenclature that still prevails in the literature today (e.g., Lelek 1987; Page and Burr 1991). Conversely, it has been proposed that whitefish should be considered as a single species because of low genetic differentiation detected in allozyme studies, and absence of either demonstrated reproductive isolation, or diagnostic morphological and allozyme characteristics between forms (Bodaly et al. 1991).

Whitefish are a typical component of northern freshwater communities and support important fisheries in most northern countries. Coregonines display a phenotypic plasticity that far exceeds what is usual in the animal kingdom (Mayr 1963), and this has hampered the understanding of their evolutionary history for over a century (Lindsey 1988). A major point of confusion in the understanding of the evolutionary history of whitefish concerns the phylogenetic relationships between Eurasian and North American populations and the role that Beringia (the region encompassing Yukon, Alaska, and the most eastern part of Siberia) has played in connecting and/or isolating the two groups during the Pleistocene.

Several studies have documented the genetic structure of whitefish on each continent separately (Franzin and Clayton 1977; Heinonen 1988; Vuorinen et al. 1986, 1993; Bodaly et al 1992). Recently, Bodaly et al. (1991) suggested, on the basis of allozyme variation, that Beringian whitefish may be more closely related to European populations than to other North American ones. However, there has been no attempt to address specifically the historical biogeography of these populations.

In recent years, analysis of the spatial distribution of polymorphisms in the nucleotide sequence of mitochondrial DNA (mtDNA) has been effective in studies of historical biogeography (Avise 1992) and particularly in demonstrating the influence of Pleistocene climatic fluctuations in shaping intraspecific genetic structure (e.g., Bernatchez et al. 1989; Lamb et al. 1989; Martin and Simon 1990; Riddle and Honeycutt 1990; Bernatchez et al. 1992; Riddle et al. 1993). In a study of the mtDNA phylogeographic structure of North American whitefish (Bernatchez and Dodson 1991), we observed four distinct phylogenetic groupings that were associated with four whitefish glacial races. A major phylogenetic break was observed between Beringia and the rest of North America, which corroborated previously documented discontinuities in morphology and isozyme frequencies (Franzin and Clayton 1977). In contrast to previous allozyme data, our study revealed the existence of two phylogenetic groups from Beringia that were as divergent from each other as they were from disjunct phylogenetic groupings characteristic of all other North American lake whitefish. The distribution of these two mtDNA groups overlapped among Beringian populations. As a scenario of stochastic lineage sorting appeared unlikely to account for this observation (Bernatchez and Dodson 1991), we proposed that this pattern of high phylogenetic discontinuity in the absence of geographic separation may have resulted from the secondary intergradation of two whitefish groups that evolved allopatrically in Eurasia and Beringia (Alaska-Yukon). In the light of those results, we extended our mtDNA analysis of whitefish populations to Europe and western Siberia to satisfy two complementary objectives: (1) to verify whether the closer genetic relationships between Eurasian and Beringian whitefish populations compared with other North American ones documented from allozyme data was also reflected in the pattern of mtDNA variation, and (2) by combining our results obtained previously for North America with those reported here for Eurasia, to present a comparison of mtDNA variation between Palearctic and Nearctic whitefish populations to propose a biogeographical hypothesis explaining the pattern of genetic differentiation observed among contemporary whitefish populations worldwide.

\section{Materials and Methods}

\section{Sample Collection and Restriction Enzyme Analysis}

A total of 210 Eurasian whitefish were collected from 1987 to 1990 among 22 populations, in addition to those 581 whitefish representing 41 populations from Beringia and the rest of North America previously reported in Bernatchez and Dodson (1991) and Vuorinen et al. (1993) (Table 1, Fig. 1). Twelve whitefish were sampled on average at each locality. Most specimens were adult fish captured during their spawning run. Fresh or frozen egg and liver samples were shipped by collaborators or transported by ourselves to the laboratory.

MtDNA was purified from liver and egg tissues by the rapid extraction method of Chapman and Powers (1984) as modified by Bernatchez et al. (1988). MtDNA aliquots were digested with eight hexameric (DraI, HindIII, PvuII, SmaI, $X m n I, B g l$, PstI, BamHI), four multihexameric (AvaI, BanI, HaeII, HincII) and one multipentameric (AvaII) restriction enzymes. MtDNA fragments were electrophoretically separated on $0.8 \%$ and $1.2 \%$ agarose gels. Restriction fragments were revealed either by ethidium bromide staining or hybridization with a highly purified radiolabelled total mtDNA probe (Bernatchez and Dodson 1990a). Fragment sizes were estimated by comparison with digests of phage $\lambda$ DNA with HindIII and EcoRI-HindIII double digest. No attempt to visualize fragments less than 350 base pairs was made. Distinct single endonuclease patterns were identified by a specific letter in order of appearance. Each fish was assigned a multiletter code which described its mtDNA haplotype.

\section{Data Analysis}

The 53 mtDNA genotypes identified in Eurasian populations were added to the 44 described by Bernatchez and Dodson (1991). The entire data set was subjected to both distance and character-based analyses. The distance measures used were estimates of nucleotide sequence divergence $(P)$ among mtDNA genotypes calculated by the site approach of Nei and $\mathrm{Li}$ (1979). Using the same method that was used for North American whitefish (Bernatchez and Dodson 1991), site differences between Eurasian whitefish mtDNA genotypes were inferred from changes in fragment patterns because these could be accounted for by specific site gains or losses. The resulting restriction site presence-absence matrix was used in character-based analyses to generate phylogenetic trees according to Wagner parsimony criteria using the MIX program from the PHYLIP 3.4 
TABLE 1. Location of sampled whitefish (Coregonus sp.) populations. Numbers preceding location names refer to positions on the map. Taxonomic designations refer to traditional morphological classification largely based on continent of origin and gill-raker numbers and still widely used at the present time (sources: Scott and Crossman 1973; Lelek 1987; Page and Burr 1991).

\begin{tabular}{|c|c|c|}
\hline Sample location & $\begin{array}{c}\text { Traditional taxonomic } \\
\text { designation }\end{array}$ & $N$ \\
\hline 1. Mira R., Nova Scotia & clupeaformis & 12 \\
\hline 2. Grand L., New Brunswick & clupeaformis & 12 \\
\hline 3. L. Témiscouata, Québec & clupeaformis & 12 \\
\hline 4. Cliff L., dwarf ecotype, Maine & clupeaformis & 16 \\
\hline 5. Spider L., dwarf ecotype, Maine & clupeaformis & 12 \\
\hline 6. Second Musquacook L., Maine & clupeaformis & 9 \\
\hline 7. Cliff L., normal ecotype, Maine & clupeaformis & 12 \\
\hline 8. L. Saint-François, Québec & clupeaformis & 12 \\
\hline 9. L. Champlain, Québec & clupeaformis & 12 \\
\hline 10. Saint-Lawrence R., Québec & clupeaformis & 13 \\
\hline 11. Réservoir Kipawa, Québec & clupeaformis & 12 \\
\hline 12. Koksoak R., Québec & clupeaformis & 15 \\
\hline 13. Povungnituk R., Québec & clupeaformis & 24 \\
\hline 14. Réservoir Manic V, Québec & clupeaformis & 10 \\
\hline 15. Squaw L., Québec & clupeaformis & 12 \\
\hline 16. Altikamagen L., Québec & clupeaformis & 9 \\
\hline 17. Inukjuak R., Québec & clupeaformis & 12 \\
\hline 18. Great Whale R., Québec & clupeaformis & 9 \\
\hline 19. La Grande R., Québec & clupeaformis & 20 \\
\hline 20. Eastmain R., Québec & clupeaformis & 31 \\
\hline 21. Rupert River, Québec & clupeaformis & 15 \\
\hline 22. L. Ontario, Ontario & clupeaformis & 12 \\
\hline 23. L. Huron, Ontario & clupeaformis & 12 \\
\hline 24. Como L., dwarf ecotype, Ontario & clupeaformis & 36 \\
\hline 25. Como L., normal ecotype, Ontario & clupeaformis & 44 \\
\hline 26. L. Superior, Ontario & clupeaformis & 10 \\
\hline 27. L. Michigan, Michigan & clupeaformis & 11 \\
\hline 28. L. Michigan, Michigan & clupeaformis & 11 \\
\hline 29. South Indian L., Manitoba & clupeaformis & 12 \\
\hline 30. Jack Fish L., Sakatchewan & clupeaformis & 12 \\
\hline 31. Wabamum L., Alberta & clupeaformis & 12 \\
\hline 32. Great Slave L., Northwest Territory & clupeaformis & 12 \\
\hline 33. Crooked R., British Columbia & clupeaformis & 12 \\
\hline 34. Fort McPherson, Northwest Territory & clupeaformis & 12 \\
\hline 35. Arctic Red R., Northwest Territory & clupeaformis & 14 \\
\hline 36. Squanga L., low gill-raker ecotype, Yukon & clupeaformis & 12 \\
\hline 37. McEvoy L., Yukon & clupeaformis & 12 \\
\hline 38. Dezadeash L., low raker ecotype, Yukon & clupeaformis & 9 \\
\hline 39. Chatanika R., Alaska & nelsoni & 12 \\
\hline 40. Yukon R., Alaska & nelsoni & 11 \\
\hline 41. Minnesota L., Alaska & pidschian & 12 \\
\hline 42. Kiiminkijoki R., Finland & lavaretus & 14 \\
\hline 43. Mickelsörarna, Finland & widegreni & 20 \\
\hline 44. Öja, Finland & lavaretus & 12 \\
\hline 45. Kyrönjoki R., Finland & lavaretus & 8 \\
\hline 46. Lestijoki R., Finland & lavaretus & 11 \\
\hline 47. Malaxa R., Finland & lavaretus & 4 \\
\hline 48. Dyhajarvi L., Finland & muksun & 4 \\
\hline 49. Kymijoki R., Finland & lavaretus & 6 \\
\hline 50. Niewleno L., Poland & lavaretus & 11 \\
\hline 51. Sperillen L., Norway & lavaretus & 11 \\
\hline 52. Constance L., Blaufelchen, Switzerland & wartmani & 12 \\
\hline 53. Constance L., Gangfisch, Switzerland & oxyrhynchus & 12 \\
\hline 54. Brienz L., winter spawning, Switzerland & oxyrhynchus & 12 \\
\hline 55. Brienz L., spring spawning, Switzerland & oxyrhynchus & 12 \\
\hline 56. Brienz L., fall spawning, Switzerland & oxyrhynchus & 12 \\
\hline 57. L. Léman, France/Switzerland & fera $=$ nasus & 10 \\
\hline 58. L. d'Aiguebelette, France & lavaretus & 12 \\
\hline 59. L. d'Annecy, France & lavaretus & 5 \\
\hline
\end{tabular}




\begin{tabular}{lcc}
\hline \multicolumn{1}{c}{ Sample location } & $\begin{array}{c}\text { Traditional taxonomic } \\
\text { designation }\end{array}$ & $N$ \\
\hline 60. Loch Lomond, Scotland & lavaretus & 8 \\
61. Kola Peninsula, Russia & lavaretus & 1 \\
62. Lapin R, Siberia & pidschian & 2 \\
63. Sos'va R., Siberia & pidschian & 2 \\
\hline
\end{tabular}

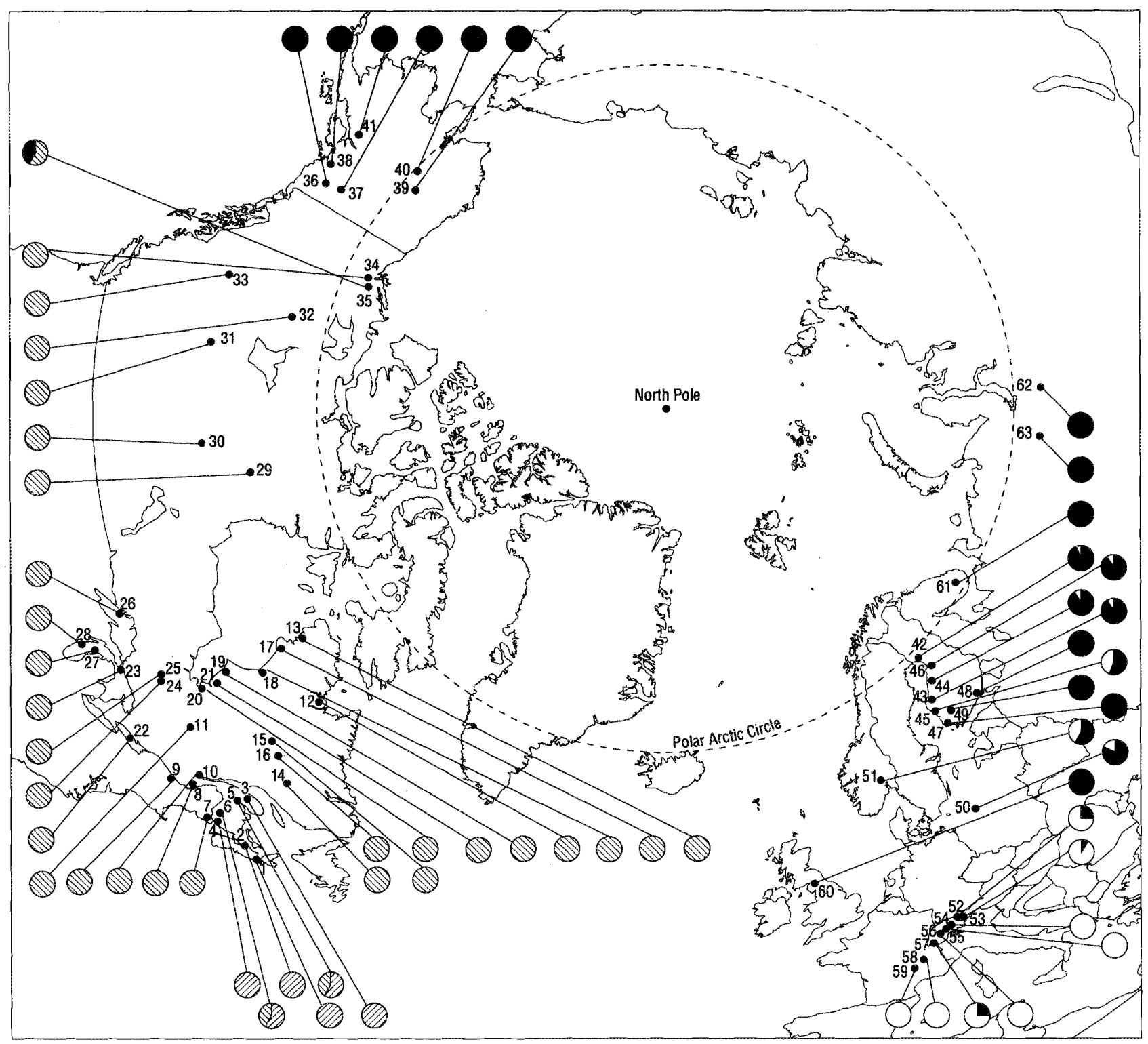

FIG. 1. Location map of sampled whitefish populations, and geographic distribution of major mtDNA phylogenetic groups identified in character-based analysis. Group I = cross hatched; group Ia = reversed cross-hatched; group II = dotted; group III = solid; group IV = open.

computer package (Felsenstein 1992). Synplesiomorphic and autapomorphic characters were omitted from the site matrix, leaving only phylogenetically informative data for tree construction. As numerous trees of equal length were found, a consensus tree and bootstraping estimates on branches were estimated by running 100 bootstrap replicates with the BOOT program from PHYLIP. Phylogenetic trees were rooted to a close relative of whitefish, the vendace ( $C$. albula) (Bodaly et al. 1991; Bernatchez et al. 1991). As a measure of inter- and intra-population genetic diversity, we also computed the maximum-likelihood estimation of the average number of nucleotide substitutions per site within populations $(\pi$, nucleotide diversity) and among populations ( $d$, nucleotide divergence) (Nei and Tajima 1981, 1983; Nei 1987). The 


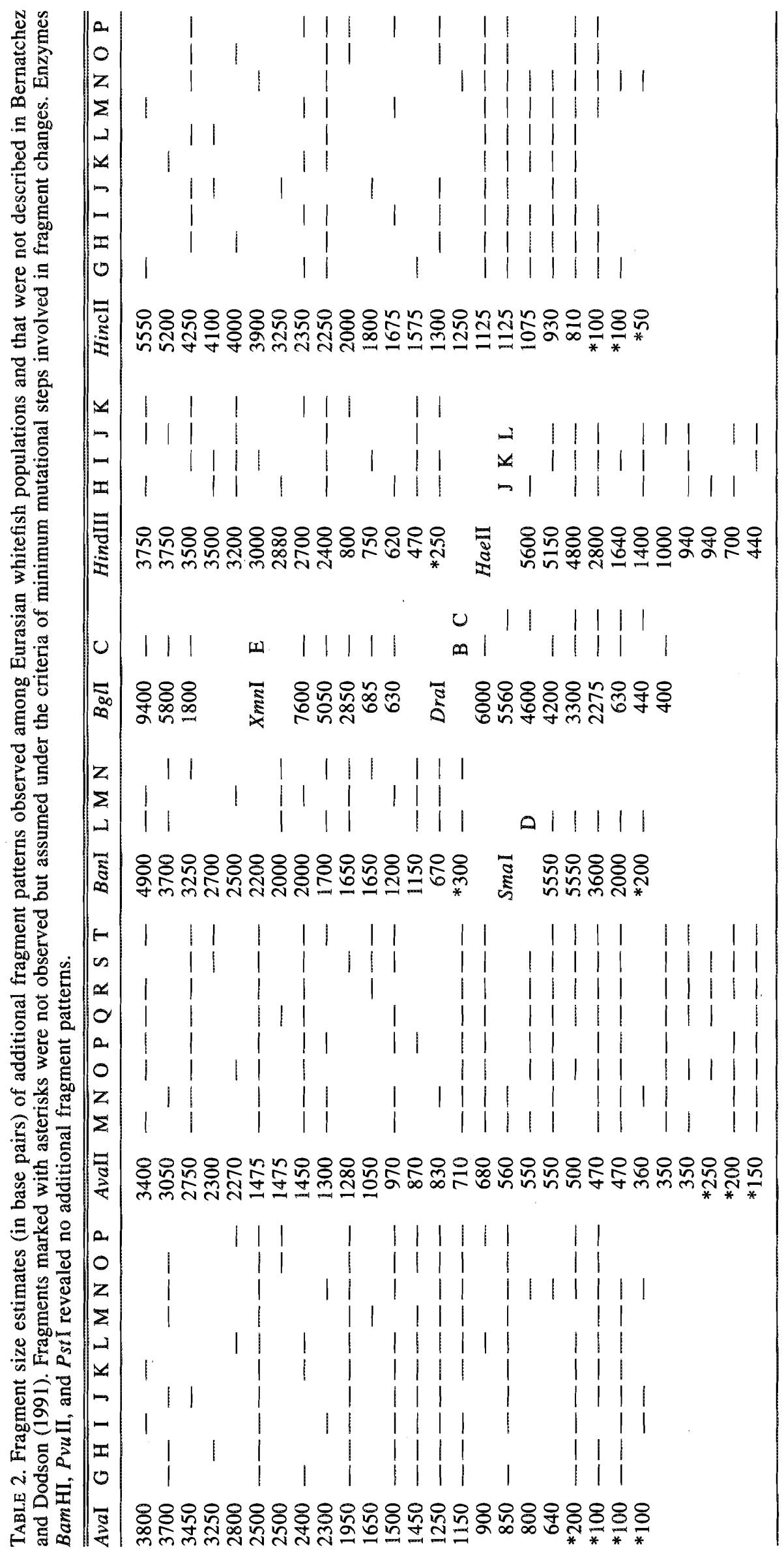


distance matrix of net nucleotide divergence among populations was used to construct a phenogram clustering all Nearctic and Paleartic populations by UPGMA.

\section{Results}

Phylogenetic Differentiation of mtDNA Groupings and their Geographic Distribution

The 13 enzymes used allowed the recognition of 138 different restriction sites that comprised a total of 45 synapomorphic sites. Fragment patterns generated for each enzyme among North American populations are detailed in Bernatchez and Dodson (1991), whereas additional patterns observed only among Eurasian populations are presented in Table 2. A total of 97 differentiated whitefish mtDNA haplotypes were observed among all 63 populations. A description of composite haplotypes observed in North America along with their distribution was presented by Bernatchez and Dodson (1991), and those observed in Eurasia are presented in Table 3. As illustrated by the topology of the majority-rule consensus tree (Fig. 2), all haplotypes clustered in five major mtDNA groups that were supported at more than $75 \%$ bootstrap level, indicating that they represented five distinct monophyletic groupings. The rooting of the tree with $C$. albula was between groups I-II and groups III-IV assemblages.

MtDNA genotypes observed in Beringia belonged to two distinct phylogenetic groups (Fig. 1). Group II consisted of mtDNA genotypes endemic to Beringia and corresponds to phylogenetic group A of Bernatchez and Dodson (1991). MtDNA genotypes that composed the second Beringian group (B in Bernatchez and Dodson 1991) clustered with numerous additional genotypes (group III) that were widely distributed among European and Siberian populations (Fig. 1). This mtDNA group dominated all Beringian populations sampled. Mean percent sequence divergence among Beringian and Eurasian mtDNA haplotypes falling within this same phylogenetic group B generally differed by less than $P=$ 0.005 (range $0.001-0.0057$ ) and generally implied few mutational changes. For instance, the most abundant and widespread haplotype observed in Beringia (haplotype 29), differed by a single site $(P=0.001)$ from one of the most abundant genotypes (genotype 92 ) found in Finland and Siberia, two restriction sites $(P=0.002)$ from genotype 97 found in Finland, and two restriction sites $(P=0.002)$ from genotype 66 observed in Europe.

In addition to mtDNA group III, haplotypes observed among European populations clustered in an additional major mtDNA group (IV) differing by a XmnI and a BanI diagnostic restriction site (Fig. 2). Phylogenetic groups III and IV exhibited a strong geographic pattern of distribution (Fig. 1). Group III dominated all the more northern populations from Scotland, Norway, Finland, and Russia, as well as the Polish population, representing $92 \%$ of all whitefish from these locations. In fact, group III was also fixed in three populations and dominated in all others from Alaska and Yukon, representing $78 \%$ of all whitefish sampled. Conversely, group IV characterized $88 \%$ of all whitefish samples from central alpine lakes in France, Switzerland, and Germany, and was absent from Beringia. In contrast, extensive dispersal of several individual mtDNA haplotypes was observed in very distant populations belonging to wellisolated water drainages (Table 1). For instance, genotype 66 was observed in Poland, Switzerland, Finland, Norway, and
Scotland, and genotype 87 was observed throughout the European range except in Scotland. It is, however, not possible to refute the possibility that the apparent dispersal is the result of artificial stock transfer from one region to the other.

All whitefish haplotypes sampled in North America outside Beringia constituted a mtDNA group (group I) that showed a distinct phylogeographic separation from other groups (Fig. 1). This assemblage corresponds to phylogenetic group C described in Bernatchez and Dodson (1991). Within this group, haplotypes 25-28 (Group Ia) also formed a distinct assemblage (group D in Bernatchez and Dodson 1991) that exhibited a disjunct geographic distribution. This assemblage characterized whitefish of Acadian refugium origin (Bernatchez and Dodson 1991). Distinct geographic patterns of distribution exhibited by other minor haplotype groupings (haplotypes 17-22) suggested the existence of whitefish issued from an Atlantic refugium (detailed in Bernatchez and Dodson 1991).

\section{Nucleotide Diversity Among and Within Populations}

The distance matrix of net nucleotide divergence among populations was used to construct a phenogram clustering all studied populations (Fig. 3). The tree clearly showed that Beringian populations clustered more closely to EuropeanSiberian $(d<0.003)$ than other North American populations $(d=0.009)$. This reflects the dominance of phylogenetic group III in Beringia. However, Beringian populations did not compose a distinct cluster and were also highly differentiated among themselves, in some instances as much as they were from European populations. This was largely caused by the differential distribution of phylogenetic groups II and III as well as fixation of unique haplotypes in some populations (e.g., Dezadeash Lake and Minnesota Lake; Table 1). In Europe and Siberia, nucleotide divergence among populations was very low in all cases $(d<0.002)$. Nevertheless, two major population clusters were observed. Populations of central alpine lakes clustered distinctively from all others, which reflects the predominance of mtDNA Group IV in this region. The other population cluster included all populations from England, Scandinavia, Russia, and Poland. The interpopulation genetic differentiation within each cluster was extremely low, as demonstrated by $d$ values that were generally less than 0.0005 . Within North American populations outside Beringia, those that composed the Acadian assemblage described by Bernatchez and Dodson (1991) also composed a distinct cluster.

No clear association was observed between population clustering patterns and traditional taxonomic designation. For instance, populations classified as $C$. clupeaformis belonged either to the distinct North American or Beringian-Eurasian groupings (Table 1, Fig. 3). Conversely, populations with different taxonomic designation fell within the same cluster and were very slightly genetically differentiated (e.g., C. lavaretus, C. oxyrhynchus, and C. fera in central Europe cluster or $C$. lavaretus, C. wartmani, C. muksun, and $C$. pidschian in the northern Europe cluster).

Figure 3 illustrates the distinction in nucleotide diversity observed within non-Beringian North American populations as opposed to Beringian and European populations. Nucleotide diversity in North America was nil or extremely low in most cases (mean $=0.0007$ ), with the exception of the Mackenzie Delta population, which represented the only 


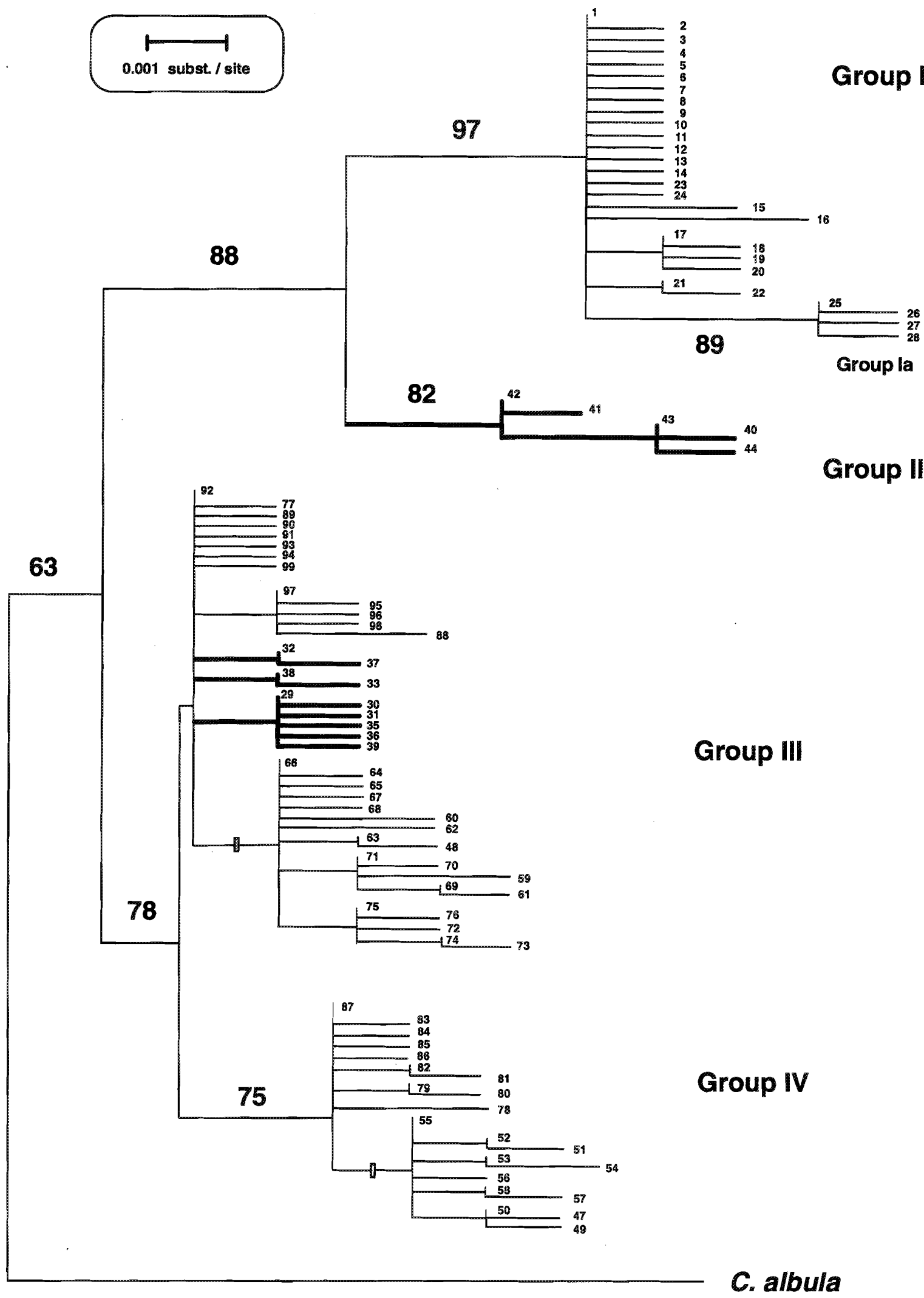

FIG. 2. Majority-rule consensus tree clustering $97 \mathrm{mtDNA}$ genotypes observed among 791 whitefish representing 63 populations. Numbers at the termini refer to haplotype definitions in Table 1. Group I, Ia, II, and III correspond to phylogenetic groups C, D, A, and $B$, respectively, described in Bernatchez and Dodson (1991). Branches in bold identify haplotypes that were found in Beringia only. Bootstrap estimates (in percentages) are given along branches. The tree was rooted using $C$. albula as an outgroup. The scale of 0.001 substitution/site corresponds to one restriction site difference. The small rectangles across branches in Group III and IV indicate length mutations. 


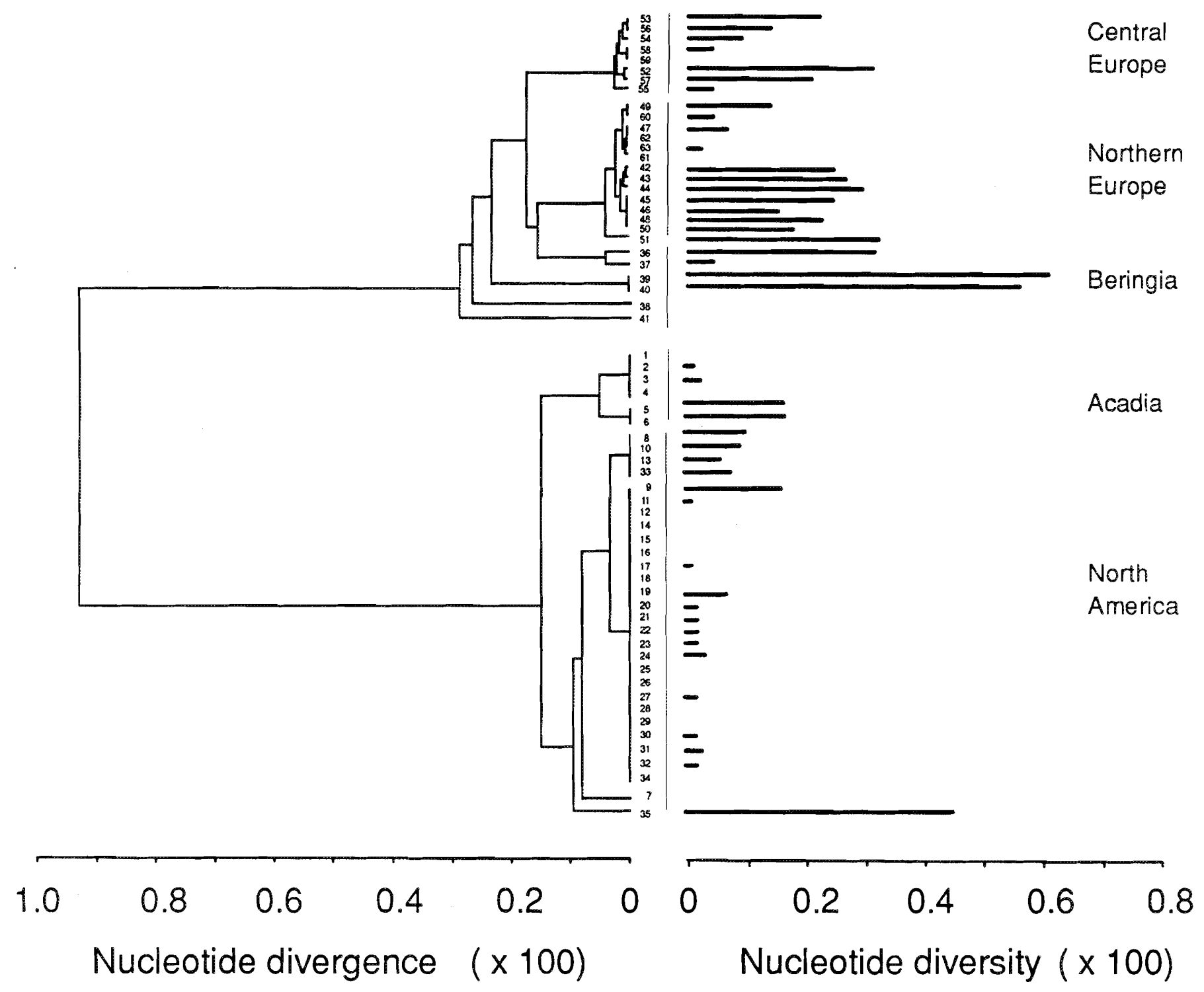

FIG. 3. UPGMA phenogram clustering whitefish populations according to the distance matrix resulting from maximum likelihood estimation of the net average number of nucleotide substitutions per site between populations ( $d$, nucleotide divergence; Nei 1987). Intrapopulation nucleotide diversity $(\pi)$ is expressed graphically on a horizontal scale next to each population. Numbers next to each population refer to Fig. 1. Names of the five major population clusters refer to their broad geographic distribution: Acadia (populations of Eastern North America diagnostically characterized by group Ia); North America (populations characterized by phylogenetic group I (excluding Ia)); Beringia (includes populations from Alaska and Yukon); central Europe (refers to central alpine lakes populations); and northern Europe (refers to Scottish, Scandinavian, Polish, and Russian populations).

overlap of Beringian (group III) and other North American (group I) haplotypes. In contrast, Beringian and European populations typically exhibited higher nucleotide diversity (mean $=0.0026$, and 0.0018 , respectively).

\section{Discussion}

Phylogeographic Patterns among Palearctic and Nearctic Whitefish Populations

It was conceivable, a priori, that divergent mtDNA groups were by chance retained within the same Beringian whitefish population in the absence of historical population separation (Neigel and Avise 1986). However, this scenario appears unlikely for the following reasons. First, such a stochastic model of lineage sorting cannot account for the nonstochastic distribution of the two Beringian mtDNA groups observed in Eurasia. Second, nonstochastic spatial discontinuity among much less differentiated mtDNA clades was observed in other regions of the whitefish distribution range (Bernatchez and Dodson 1990b). Third, although the retention of divergent (approximately 1\% divergence and more) lineages within the same population is theoretically possible if long-term effective population size remains large, there is very little empirical support for that scenario in the literature, as this phenomenon has been observed in only four instances in vertebrates (Avise et al. 1992).

Therefore, the most rational explanation for the geographic distribution of these groupings appears to be that Beringia was recolonized by a whitefish group that dispersed extensively in Eurasia, and subsequently intergraded with an endemic Beringian whitefish group. Also, the much closer genetic relationships between Eurasian and Beringian whitefish populations 
TABLE 3. Composite definitions, absolute abundance $(N)$, and geographic localization of whitefish mtDNA haplotypes observed among 22 Palearctic whitefish populations. Haplotype numbers start from 47 for a direct continuation of Nearctic whitefish haplotypes described in Table 2 of Bernatchez and Dodson (1991). Restriction enzymes are (in order) AvaI, AvaII, BanI, BgII, DraI, HaeII, HincII, HindIII, PvuII, SmaI, XmnI, BamHI, and PstI. Capital letters refer to fragment patterns described in Bernatchez and Dodson (1991) and in Table 2. Population numbers refer to location names listed in Table 1.

\begin{tabular}{|c|c|c|c|c|c|c|c|c|c|c|c|c|c|c|c|}
\hline \multicolumn{14}{|c|}{ Composite haplotypes } & \multirow{2}{*}{$\frac{N}{1}$} & \multirow[t]{2}{*}{ Population } \\
\hline 47 & $\mathrm{O}$ & $\mathbb{L}$ & $\mathbf{L}$ & $\mathrm{B}$ & A & $\mathrm{L}$ & $\mathrm{J}$ & $J$ & B & A & $\mathrm{B}$ & A & A & & \\
\hline 48 & $\mathbf{P}$ & $\mathrm{L}$ & $\mathrm{G}$ & B & A & $\mathbf{L}$ & $\mathrm{L}$ & $\mathbf{J}$ & $\mathrm{B}$ & $\mathbf{A}$ & A & A & A & 1 & 52 \\
\hline 49 & $\mathrm{O}$ & M & $\mathbf{L}$ & B & A & I & K & $\mathbf{J}$ & B & A & B & A & A & 1 & 55 \\
\hline 50 & $\mathrm{O}$ & $\mathbf{M}$ & $\mathbf{L}$ & B & A & $\mathrm{L}$ & $\mathbf{L}$ & $\mathbf{J}$ & B & A & B & A & A & 1 & 55 \\
\hline 51 & $\mathbf{G}$ & $\mathbf{L}$ & $\mathrm{N}$ & B & A & I & $\mathrm{H}$ & G & B & A & B & A & A & 2 & 52,53 \\
\hline 52 & $\mathbf{G}$ & $\mathbf{L}$ & $\mathbf{L}$ & B & A & I & $\mathrm{H}$ & G & B & A & B & A & A & 1 & 52 \\
\hline 53 & $\mathrm{G}$ & $\mathbf{M}$ & $\mathbf{L}$ & B & A & I & $\mathrm{O}$ & G & $\mathrm{B}$ & A & B & A & A & 2 & 52,53 \\
\hline 54 & $\mathbf{M}$ & $\mathbf{M}$ & $\mathrm{G}$ & B & A & $I$ & $\mathbf{P}$ & G & $\mathrm{B}$ & A & B & A & A & 2 & 52,53 \\
\hline 55 & $\mathbf{G}$ & $\mathbf{M}$ & $\mathrm{L}$ & B & A & I & $\mathbf{H}$ & $\mathrm{G}$ & B & A & B & A & A & 29 & $46,52-58$ \\
\hline 56 & $\mathrm{G}$ & $\mathbf{M}$ & $\mathrm{L}$ & $\mathrm{C}$ & A & $I$ & $\mathbf{H}$ & $I$ & B & A & $\mathrm{B}$ & A & $\mathbf{A}$ & 1 & 57 \\
\hline 57 & G & $\mathbf{M}$ & $\mathrm{L}$ & B & A & $\mathbf{K}$ & $\mathbf{H}$ & G & B & B & B & A & A & 1 & 44 \\
\hline 58 & $G$ & $\mathbf{M}$ & $\mathrm{L}$ & B & A & $\mathbf{K}$ & $\mathbf{H}$ & G & B & A & B & A & A & 1 & 42 \\
\hline 59 & G & $\mathbf{M}$ & $\overline{\mathbf{K}}$ & B & A & I & I & G & B & A & $\mathrm{E}$ & A & A & 1 & 43 \\
\hline 60 & G & $\mathrm{M}$ & $\mathrm{G}$ & B & A & I & $\mathrm{H}$ & $\mathbf{K}$ & B & A & $\mathrm{C}$ & A & A & 3 & 51 \\
\hline 61 & $\mathrm{H}$ & $\mathrm{M}$ & $\mathrm{G}$ & $\bar{B}$ & A & I & I & $\mathrm{H}$ & B & A & A & A & A & 1 & 43 \\
\hline 62 & $\mathrm{G}$ & $\mathbf{P}$ & $\mathrm{G}$ & $\mathrm{B}$ & $\mathrm{B}$ & I & $\mathrm{H}$ & $\mathbf{G}$ & B & A & A & A & A & 1 & 45 \\
\hline 63 & $\mathbf{L}$ & $\mathbf{M}$ & $\mathbf{G}$ & $\mathrm{B}$ & A & 1 & $\mathbf{H}$ & G & B & A & A & A & A & 3 & 52,53 \\
\hline 64 & $\mathbf{G}$ & $\mathbf{M}$ & $\mathbf{G}$ & B & A & I & $\mathbf{H}$ & G & B & A & A & A & $\mathbf{A}$ & 7 & 50 \\
\hline 65 & $\mathrm{~A}$ & $\mathbf{M}$ & $\mathbf{G}$ & B & A & I & $\mathrm{H}$ & G & B & A & A & A & A & 1 & 48 \\
\hline 66 & G & $\mathbf{M}$ & $\mathrm{G}$ & B & A & I & $\mathbf{H}$ & $\mathrm{G}$ & B & A & A & A & A & 13 & $43,44,48,50,57,60$ \\
\hline 67 & G & $\mathbf{M}$ & $\mathbf{M}$ & B & A & I & $\mathbf{H}$ & G & B & A & A & A & A & 1 & 57 \\
\hline 68 & G & $\mathbf{M}$ & $\mathbf{L}$ & B & A & I & $\mathrm{H}$ & G & B & A & A & A & A & 2 & 42,57 \\
\hline 69 & $\mathbf{G}$ & $\mathbf{M}$ & $\bar{G}$ & B & A & I & I & $\mathrm{H}$ & B & A & A & A & A & 1 & 43 \\
\hline 70 & $\mathbf{G}$ & $\mathbf{M}$ & $\mathrm{G}$ & B & A & 1 & $\mathbf{M}$ & $\mathrm{G}$ & B & A & A & A & A & 2 & 44,45 \\
\hline 71 & $\mathbf{G}$ & $\mathbf{M}$ & $\mathrm{G}$ & B & A & I & I & $\mathbf{G}$ & B & A & A & A & A & 12 & $42-44,46,50,51$ \\
\hline 72 & $\mathrm{G}$ & $\mathrm{N}$ & $\mathrm{G}$ & B & A & I & I & $G$ & $\mathrm{~B}$ & A & A & A & A & 2 & 43,51 \\
\hline 73 & G & $\mathrm{N}$ & $\mathbf{K}$ & B & A & I & I & G & B & A & A & A & A & 1 & 43 \\
\hline 74 & G & $\mathbf{N}$ & $\mathbf{K}$ & B & A & J & $\mathrm{H}$ & $\mathbf{G}$ & B & A & A & A & A & 1 & 44 \\
\hline 75 & G & $\mathbf{N}$ & $\mathbf{G}$ & $\mathbf{B}$ & A & I & $\mathbf{H}$ & $\mathbf{G}$ & B & A & A & $\mathrm{A}$ & A & 4 & $42,43,46,51$ \\
\hline 76 & G & $\mathbf{N}$ & $\mathbf{G}$ & $\mathbf{B}$ & A & $J$ & $\mathbf{H}$ & $\mathbf{G}$ & B & A & A & A & A & 2 & 42 \\
\hline 77 & A & $\mathbf{H}$ & $\mathbf{G}$ & C & A & A & A & $\mathbf{G}$ & B & A & A & A & A & 1 & 51 \\
\hline 78 & A & $\mathbf{M}$ & $\mathrm{L}$ & B & A & A & A & $\mathbf{J}$ & B & A & B & A & A & 1 & 56 \\
\hline 79 & A & $\mathbf{R}$ & $\mathrm{L}$ & B & A & A & A & $\mathbf{G}$ & B & A & B & A & A & 1 & 53 \\
\hline 80 & A & $\mathbf{S}$ & $\mathrm{L}$ & B & A & A & A & G & B & A & B & A & A & 1 & 53 \\
\hline 81 & A & $Q$ & $\bar{L}$ & B & A & A & B & $\mathbf{G}$ & $\bar{B}$ & A & B & A & A & 1 & 50 \\
\hline 82 & A & $\mathbf{Q}^{2}$ & $\mathrm{~L}$ & B & A & A & A & $\mathbf{G}$ & B & A & B & $\mathrm{A}$ & A & 1 & 43 \\
\hline 83 & A & $\mathrm{H}$ & $\mathrm{L}$ & $\mathrm{B}$ & A & A & B & $\mathbf{G}$ & B & A & B & $\mathrm{A}$ & A & 1 & 54 \\
\hline 84 & A & $\mathrm{H}$ & $\mathrm{L}$ & B & A & A & B & G & B & D & $\mathbf{B}$ & A & A & 1 & 49 \\
\hline 85 & A & $\mathrm{H}$ & $\mathrm{L}$ & B & A & A & $\mathbf{A}$ & G & B & $\mathrm{A}$ & $\mathrm{B}$ & $\mathrm{B}$ & A & 1 & 49 \\
\hline 86 & $\mathrm{~N}$ & $\mathrm{H}$ & $\mathrm{L}$ & $\mathbf{B}$ & A & A & A & G & B & A & B & A & A & 1 & 51 \\
\hline 87 & A & $\mathrm{H}$ & $L$ & B & A & A & A & $\mathbf{G}$ & B & A & B & A & A & 46 & $43-45,50,51,52-59$ \\
\hline 88 & I & $\mathrm{H}$ & $\mathbf{K}$ & B & A & A & B & $\mathbf{G}$ & B & A & A & A & A & 1 & 44 \\
\hline 89 & A & $\mathrm{H}$ & $\mathrm{G}$ & B & A & A & $\bar{N}$ & $\mathbf{G}$ & B & A & A & A & A & 1 & 49 \\
\hline 90 & A & $\mathrm{H}$ & G & B & $\mathrm{C}$ & A & A & $\mathbf{G}$ & B & A & A & A & A & 1 & 48 \\
\hline 91 & A & $\mathrm{H}$ & $\mathbf{G}$ & B & A & A & A & $\mathbf{G}$ & $\overline{\mathrm{B}}$ & A & A & A & B & 2 & 47,48 \\
\hline 92 & A & $\mathrm{H}$ & $\mathbf{G}$ & $\mathbf{B}$ & A & A & A & $\mathbf{G}$ & B & A & A & A & A & 11 & $42,43,46,47,49,61,62$ \\
\hline 93 & $\mathbf{J}$ & $\mathbf{H}$ & G & B & A & A & A & $\mathbf{G}$ & B & A & A & A & A & 1 & 44 \\
\hline 94 & A & $\mathbf{M}$ & $\mathbf{G}$ & B & A & A & A & $\mathbf{G}$ & $\bar{B}$ & A & A & A & A & 4 & 42,60 \\
\hline 95 & A & 0 & $\mathrm{G}$ & $\mathrm{B}$ & A & A & B & $\mathbf{G}$ & B & A & A & A & A & 4 & 43,63 \\
\hline 96 & A & $\mathbf{H}$ & $G$ & B & A & A & $\bar{B}$ & $\mathrm{H}$ & $\bar{B}$ & A & A & A & A & 1 & 44 \\
\hline 97 & A & $\mathrm{H}$ & $\mathrm{G}$ & B & A & A & B & G & B & A & A & A & A & 9 & $42,43,45-47$ \\
\hline 98 & $\mathrm{~A}$ & $\mathrm{H}$ & $\mathrm{G}$ & B & A & A & $\mathbf{G}$ & G & B & A & A & A & A & 4 & $42,43,46$ \\
\hline 99 & A & $\mathrm{T}$ & $\mathrm{G}$ & B & A & A & A & $\mathrm{G}$ & $\mathrm{B}$ & A & A & A & A & 1 & 61 \\
\hline
\end{tabular}

compared with other North American ones, as documented previously from allozymes (Bodaly et al. 1991), was reflected in $\mathrm{mtDNA}$ variation.

The fact that mtDNA haplotypes of this Eurasian group that were found in Beringia are very closely related to others that were widely distributed in the Eurasian populations that we surveyed suggests that the recolonization of Beringia by this group occured in recent evolutionary times. Furthermore, very closely related mtDNA genotypes found in populations separated by over $10000 \mathrm{~km}$, contemporary 
unconnected river drainages, and the marine Bering Strait imply an exceptional degree of dispersal and gene flow for freshwater fishes. Indeed, the levels of divergence documented among whitefish mtDNA genotypes found on two separate continents are characteristic of intrapopulation variation frequently observed in many animal groups, including fish (see literature in Avise 1989). Such a genetic structure contrasts sharply with the general observation that most freshwater fishes currently exhibit the highest levels of interpopulation gene diversity reported in any animal group (Gyllensten 1985). In fact, the broad scale continental and intercontinental geographic distribution of slightly differentiated phylogenetic assemblages observed in whitefish approaches the type of phylogeographic structure usually documented in species with life history conducive to dispersal and/or that occupy a range free of firm barriers to gene flow such as some marine organisms, bird species, and humans (Avise et al. 1992; Ball et al. 1988; Cann et al. 1987; Graves et al. 1984; Palumbi and Wilson 1990). This phenomenon most likely implies that whitefish have episodically been fragmented into several groups that subsequently dispersed extensively.

During the Pleistocene, huge glacial lakes persisted through most of Siberia, and the Beringian land bridge opened during each glacial maxima (Denton and Hughes 1981). River drainages flowing on an east-west axis developed on the bridge, which could have provided intercontinental dispersal routes for freshwater organisms (Lindsey and McPhail 1986). Whitefish of Eurasian origin may have been able to use these drainage connections to recolonize Beringia. However, in the absence of additional samples from Siberia, it is not possible at present to document the possibility that Beringian whitefish may have also used these routes to invade Eurasia, although their complete absence in Europe and our samples from Siberia (Lapin and Sos'va rivers) suggests that they never reached this region.

In contrast to the extensive dispersal of closely related haplotypes observed among northern European and Beringian populations, this study revealed that populations of northern and central Europe belonged to two phylogenetic groupings between which dispersal has been restricted. As both northern and central alpine Europe were episodically completely glaciated during the Pleistocene, both regions were most probably recolonized by two genetically distinct whitefish groups that evolved in allopatry in other regions, followed subsequently by limited intergradation. Vast areas of what is the present-day distribution range of whitefish in Eurasia remained unglaciated, especially in Siberia and were associated with extensive arctic and boreal climatic zones, expanding south to the Mediterranean coast (Flint 1971). Thus, these regions could have represented potential habitats for whitefish survival. Again, further sampling is needed in the eastern distribution range of whitefish in Eurasia to adequately document the historical biogeography of the species.

Globally, the broad-scale pattern of mtDNA variation among European populations resembled the pattern observed in North America outside Beringia where geographic populations occupied different branches of an intraspecific, phylogenetic tree. However, a major difference between North American and European (and Beringian) populations was the extremely reduced level of intrapopulation genetic diversity in North America. Bernatchez at al. (1989) argued that the dramatic difference in mtDNA diversity between anadromous whitefish populations from the Baltic Sea and Hudson Bay resulted primarily from population bottlenecks that correlated with the more important loss of potential habitat in North America than in Europe during Pleistocene glaciations. For instance, most of the North American continent north of the 40th parallel was ice covered during the Wisconsinian glacial advance. The arctic and boreal climatic zones, characteristic of the present-day distribution of whitefish, were telescoped within a relatively narrow band south of the ice sheet (Flint 1971; Fulton and Prest 1987), limiting refugia for cold-adapted species such as whitefish. This inevitably led to population reduction of cold-adapted fish species (McAllister et al. 1986), which may have resulted in an important loss of mtDNA genetic variability in North American whitefish populations. In contrast, vast areas of what is the present day distribution range of whitefish in Eurasia remained unglaciated, as described above. Thus, potential population reduction for whitefish in Eurasia may not have been as severe, resulting in a preservation of mtDNA variability.

Similarly, the difference in mtDNA diversity between Beringia, of which much remained unglaciated, and the rest of North America was attributed to differential population reduction through loss of habitat (Bernatchez and Dodson 1991). We propose that the generalized difference in mtDNA diversity between North American and Eurasian-Beringian populations is due to differences in the extent of population bottlenecks associated with differential glacier advance in different parts of the species range. Thus, low genetic diversity observed in North America corroborates the refugial concept, implying that population sizes in regions of endemism were drastically reduced for a period of time (Cracraft 1985). In contrast, the genetic divergence observed among distinct phylogenetic assemblages in Beringia and Europe suggested that several whitefish groups evolved in allopatry but does not provide evidence of any severe population reduction within each of these.

\section{Lack of Congruence Between Genotypic and Phenotypic Variation in Whitefish}

Our study indicates that traditional taxonomic units in whitefish do not reflect natural assemblages resulting from monophyletic divergence. Firstly, our results agreed with those obtained from allozymes in demonstrating that the major dichotomic distinction between $C$. lavaretus and C. clupeaformis based on continent of origin does not reflect the evolutionary history of whitefish. In fact, should such a distinction be maintained, Alaska-Yukon populations should naturally be included within the $C$. lavaretus complex (Fig. 3). However, because of the lack of diagnostic morphological distinction between both groups, and because levels of mtDNA variation (as in allozyme variation) observed between both continents are more representative of intraspecific variation (generally less than $P=0.001$; see Billington and Hebert 1991 for a review), we suggest that $C$. lavaretus and $C$. clupeaformis should be recognized as a single, variable and circumpolar ranging species, Coregonus lavaretus, according to the most ancient name in use.

The taxonomic recognition among Eurasian populations is much more complicated due to the many examples of persistent reproductive isolation among morphologically distinct ecotypes, thus fulfilling a major criteria of the biological species concept (e.g., Svärdson 1979; Kirchhofer 
and Tschumi 1986). Furthermore, the present study suggested that the morphological radiation observed within both northern and central Europe would have occurred following the last glacier retreat, some $18000 \mathrm{yr}$ ago. In addition, our results indicated numerous cases of polyphyletic and paraphyletic (distinct morphotypes genetically more closely related to each other than to identical ones from other regions) assemblages resulting from the traditional taxonomic designation. This casts doubts on the validity and utility of different taxonomic designations of whitefish populations based solely on morphological patterns.

\section{Acknowledgments}

We thank Suzie Boivin, and Françoise Colombani for technical assistance and all collaborators who kindly provided fish samples or field assistance, namely: David J. Basley, Maine Department of Inland Fisheries and Wildlife in Ashland; and Wesley White, Department of Fisheries and Oceans Canada (DFO) in Halifax. Patrice Couture; Ken Alt, Northern Alaska Fisheries Service in Fairbanks; Bob Wescott, British Columbia Ministry of Environment; Bryant Bidgood, Alberta Fisheries Research; Bill Sawchyn, Saskatchewan Park Recreation and Culture; Guy Fleisher, Inter-tribal Fisheries; Wayne McCallum and Ted Schaner, Ontario Ministry of Natural Resources; Alex Gordon, Société Makivik; Doug Barr, McGill Subarctic Research Station; Aquarium du Québec; Pierre Dumont, Jean Lamoureux, and Gaston Charest, Ministère du Loisir, de la Chasse et de la Pêche, Québec; Drew Bodaly, Peter Etherton, George Low, and Vic Gillman, Department of Fisheries and Oceans Canada; Michel Leblanc, Laniel; M. Luczinski, C. Rhulé, A. Kirchkofer, D. Gerdeaux, A. Ferguson, B. Nielsen, T. Edge, and the late C. Mills. This research was funded by a Natural Sciences and Engeneering Research Council (NSERC) of Canada strategic grant to JJ.D., Helga Guderley, and Dominick Pallotta and by a grant from the Department of Fisheries and Oceans of Canada to J.J.D. L.B. was supported by NSERC and Fonds pour la Formation de Chercheurs et d'Aide à la Recherche (Québec) postgraduate scholarships. Contribution to the program of GIROQ (Groupe Interuniversitaire de Recherches Océanographiques du Québec).

\section{References}

AVISE, J.C. 1989. Gene trees and organismal histories: a phylogenetic approach to population biology. Evolution 43: 1192-1208.

AVISE, J.C. 1992. Molecular population structure and the biogeographic history of a regional fauna: a case history with lessons for conservation biology. Oikos 63: 62-76.

Avise, J.C., R.T. Alikauskas, W.S. Nelson, and C.A. Davidson. 1992. Matriarchal population genetic structure in an avian species with female natal philopatry. Evolution 46: 1084-1096.

Ball, R.M., S. Freeman, F.C. James, E. Bermingham, and J.C. Avise. 1988. Phylogeographic population structure of red-winged blackbirds assessed by mitochondrial DNA. Proc. Nat. Acad. Sci. U.S.A. 85: $1558-1562$.

BERG, L.S. 1948. Freshwater fishes of the U.S.S.R. and adjacent countries. Zool. Inst. Akad. Nauk SSSR 1(27): 466 p. (Transl. from Russian by Office of Technical Services, Department of Commerce. Washington, DC 1962).

Bernatchez, L., F. Colombani, and J.J. Dodson. 1991. Phylogenetic relationships among the subfamily Coregoninae as revealed by mitochondrial DNA restriction analysis. J. Fish Biol. 33(Suppl. A): 283-290.

Bernatchez, L., AND J.J. Dodson. 1990a. Mitochondrial DNA variation among anadromous populations of cisco (Coregonus artedii) as revealed by restriction analysis. Can. J. Fish. Aquat. Sci. 47: 533-543.

BERNATCHEZ, L., AND J.J. DODsON. 1990b. Allopatric origin of sympatric populations of lake whitefish (Coregonus clupeaformis) revealed by mitochondrial DNA restriction analysis. Evolution 44: 1263-1271.

Bernatchez, L., AND J.J. DODSON. 1991. Phylogeographic structure in mitochondrial DNA of the lake whitefish (Coregonus clupeaformis) and its relation to Pleistocene glaciations. Evolution 45: 1016-1035.
Bernatchez, L., J.J. Dodson, AND S. Borvin. 1989. Population bottlenecks: influence on mitochondrial DNA diversity and its effect in coregonine stock discrimination. J. Fish Biol. 35(Suppl. A): 233-244.

Bernatchez, L., R. GuYomard, and F. BONhOMmE. 1992. DNA sequence variation of the mitochondrial control region among geographically and morphologically remote European brown trout Salmo trutta populations. Mol. Ecol. 1: 161-173.

Bernatchez, L., L. Savard, J.J. Dodson, and D. Pallotta. 1988. Mitochondrial DNA sequence heterogeneity among James-Hudson Bay anadromous coregonines. Finn. Fish. Res. 9: 17-26.

Billington, N., AND P.D.N. HeberT. 1991. Mitochondrial DNA diversity in fishes and its implications for introductions. Can. J. Fish. Aquat. Sci. 48: 80-94.

Bodaly, R.A., J.W. Clayton, C.C. Lindsey, and J. Vuorinen. 1992. Evolution of lake whitefish (Coregonus clupeaformis) in North America during the Pleistocene: genetic differentiation between sympatric populations. Can. J. Fish. Aquat. Sci. 49: 769-779.

BODALY, R.A., J. VUORINEN, R.D. WARD, M. LUCZYNSKI, AND J.D. REIST, 1991. Genetic comparisons of New and Old World coregonid fishes. J. Fish Biol. 38: 37-51.

BRIGGS, J.C. 1986. Introduction to the zoogeography of North American fishes, p. 1-16. In C.H. Hocutt and E.O. Wiley [ed.] Zoogeography of North American freshwater fishes. John Wiley \& Sons, New York, NY.

CANN, R.L., M. Stoneking, AND A.C. Wilson. 1987. Mitochondrial DNA and human evolution. Nature (Lond.). 325: 31-36.

Chapman, R.W., AND D.A. Powers. 1984. A method for the rapid isolation of mitochondrial DNA for fishes. Tech. Rep. UM-SG-TS-84-05: Maryland Sea Grant Program, College Park, MD. 11 p.

CRACRAFT, J. 1985. Historical biogeography and patterns of differentiation within the South American avifauna: areas of endemism. Ornith. Monogr. 36: 49-84.

Denton, G.H., AND T.J. Hughes. 1981. The Last Great Ice Sheets. John Wiley \& Sons, New York, NY. 484 p.

FELSENSTEIN, J. 1992. PHYLIP (Phylogeny inference package) version 3.4. Department of Genetics, SK-50, University of Washington, Seattle, WA 98195, USA.

FLINT, R.F. 1971. Glacial and Quaternary Geology. John Wiley and Sons, Inc., New York, NY.

Franzin, W.G., AND J.W. Clayton. 1977. A biochemical genetic study of zoogeography of lake whitefish (Coregonus clupeaformis) in western Canada. J. Fish. Res. Board Can. 34: 617-625.

Fulton, R.J. AND J.T. ANDREws [ed.]. 1987. The Laurentide ice sheet. Géogr. Phys. Quat. 41: $318 \mathrm{p}$.

FULTON, R.J., AND V.K. PREST. 1987. The Laurentide ice sheet and its significance. Géogr. Phys. Quat. 41: 181-186.

Graves, J.E., S.D. Ferris, AND A.E. Dizon. 1984. Close genetic similarity of Atlantic and Pacific skipjack tuna (Katsuwonus pelamis) demonstrated by restriction endonuclease analysis of mitochondrial DNA. Mar. Biol. 79: 315-319.

GyLLENSTEN, U. 1985. The genetic structure of fish: differences in the intraspecific distribution of biochemical genetic variation between marine, anadromous and freshwater species. J. Fish Biol. 26: 691-699.

HEINONEN, M. 1988. Taxonomy and genetic variation of whitefish (Coregonus sp.) in Lake Saimaa. Finn. Fish. Res. 9: 39-47.

KrRChHORFER, A., AND P.A. TsChUMI. 1986. Age structure and growth of coregonid fish populations in Lake Thun. Ergeb. Limnol. 22: 303-318.

Kontrimavichus, V.L. 1973. Beringia in the Cenozoic era. Oxonian Press Pvt. Ltd., New Delhi. 724 p.

LAMB, T., J.C. Avise, AND J.W. GibBons. 1989. Phylogeographic patterns in mitochondrial DNA of the desert tortoise (Xerobates agassizi) and evolutionary relationships among the North American gopher tortoises. Evolution. 43: 76-87.

Lelex, A. 1987. The freshwater fishes of Europe. Vol. 9. Threatened fishes of Europe. European Commitee for the Conservation of Nature and Natural Resources. Aula-Verlag, Wiesbaden. 343 p.

LINDSEY, C.C. 1988. The relevance of systematics to coregonid management Finn. Fish. Res. 9: 1-10.

LiNDSEY, C.C., AND J.D. MCPhalL. 1986. Zoogeography of fishes of the Yukon and Mackenzie basins, p. 639-674. In C.H. Hocutt and E.O. Wiley [ed.] Zoogeography of North American freshwater fishes. John Wiley \& Sons, New York, NY.

Martin, A., AND C. SimON. 1990. Differing levels of among-population divergence in the mitochondrial DNA of periodical cicadas related to historical biogeography. Evolution 44: 1066-1080.

MAYR, E. 1963. Animal species and evolution. Oxford University Press, London. $797 \mathrm{p}$.

McAllister, D.E., S.P. Platania, F.W. Shueler, M.E. Baldwin, and 
D.S. LEE. 1986. Icthyofaunal patterns on a geographic grid, p. 18-50. In C.H. Hocutt and E.O. Wiley [ed.] The zoogeography of North American freshwater fishes. John Wiley \& Sons, New York, NY.

NEI, M. 1987. Molecular evolutionary genetics. Columbia University Press, New York, NY.

NEI, M., AND W.H. LI. 1979. Mathematical model for studying genetic variation in terms of restriction endonucleases. Proc. Natl. Acad. Sci. U.S.A. 76: 5269-5273.

NEI, M., AND F. TAJIMA. 1981. DNA polymorphism detectable by restriction endonucleases. Genetics 97: 145-163.

NEI, M., AND F. TAJIMA. 1983. Maximum likelihood estimation of the number of nucleotide substitutions from restriction sites data. Genetics 105: 207-217.

NeIGEL, J.C., AND J. C. AvisE. 1986. Phylogenetic relationships of mitochondrial DNA under various demographic models of speciation, p. 515-534. In E. Nevo and S. Karlin [ed.] Evolutionary processes and theory. Academic Press, New York, NY.

Page, L.M., AND B.M. BURR. 1991. Freshwater Fishes. The Peterson Field Guide Series. Vol. 42. Houghton Mifflin Co., Boston. 432 p.

PAlumbi S.R., AND A.C. WILSON. 1990. Mitochondrial DNA diversity in the sea urchins Strongylocentrotus purpuratus and $S$. droebachiensis. Evolution 44: 403-415.
RIDDLE, B.R., AND R.L. HoNEYCUTT. 1990. Historical biogeógraphy in North American arid regions: an approach using mitochondrial-DNA phylogeny in grasshopper mice (genus Onychomys). Evolution 44: $1-15$.

RiddLe, B.R., R.L. HoneYCUTT, AND P.L. LeE. 1993. Mitochondrial DNA phylogeography in northern grasshopper mice (Onychomys leucogaster) the influence of Quaternary climatic oscillations on population dispersion and divergence. Mol. Ecol. 2: 183-193.

SCOTT, W.B., AND E.J. Crossman. 1973. Freshwater fishes of Canada. Bull. Fish. Res. Board Can. 184: 1026 p.

SVÄRDSON, G. 1979. Speciation of Scandinavian Coregonus. Rep. Inst. Freshwater Res. Drottningholm 57: 1-95.

Vuorinen, J.A., R.A. Bodaly, J.D. Reist, L. Bernatchez, AND J.J. DODSON. 1993. Genetic and morphological differentiation between dwarf and normal size forms of lake whitefish (Coregonus clupeaformis) in Como Lake, Ontario. Can. J. Fish. Aquat. Sci. 50: 210-216.

Vuorinen, J., A. Champigneulle, K. Dabrowski, R. Eckmann, and R. Rosch. 1986. Electrophoretic variation in central European coregonid populations. Ergeb. Limnol. 22: 291-298. 